\title{
Specific features of the development of Rhopalosiphum padi in connection with migration and transfer of the viral infection to host and non-host plants using potato as an example
}

\author{
ELENA S. GANDRABUR ${ }^{\boldsymbol{\gamma}}$, ALLA B. VERESHCHAGINA \\ All-Russian Research Institute of Plant Protection. Podbelskogo 3, St. Petersburg - Pushkin, 196608, Russian Federation \\ "email: helenagandrabur@gmail.com
}

Manuscript received: 22 April 2019. Revision accepted: 31 October 2019

\begin{abstract}
Gandarabur ES, Vereshchagina AB. 2019. Specific features of the development of the bird cherry-oat aphid Rhopalosiphum padi (L.) in connection with migration and transfer of the viral infection to host and non-host plants using potato as an example. Biodiversitas 20: 3439-3447. Using Rhopalosiphum padi (L.), which lives in the North-West of the Russian Federation, as an example, the long-term data on the timing of its spring migration from bird cherry to herbaceous plants are summarized and their analysis, related to the wing formation in aphid colonies and the accompanying weather conditions, is given. It was found out, those peculiarities of behavior of spring emigrants of $R h$. padi during the host selection depend on the motivation for a long-distance flight, include repeated take-off and testing and may be accompanied by visits to the non-host plants during 4 days. Migration and settling behavior of aphids underlie their ability to transfer non-persistent viruses to host and non-host plants. The obtained data allow adjusting the methods of plant protection including the viral infection.
\end{abstract}

Keywords: Aphids, migration, life cycle, potatoes, virus transmission, wheat

\section{INTRODUCTION}

Aphids (Hemiptera, Sternorrhyncha, Aphididae) are an important group of insects with about 5000 species described so far (Remaudiere \& Remaudiere 1997). The characteristics of these insects such as host alternation, polymorphism, and parthenogenesis enable them fast reproduction, migration, and hence damage to economic crops (Dixon 1992). Apart from the direct damage inflicted by sucking nutrients, aphids transmit a large number of plant viruses. Currently, about 300 species of aphids are known as vectors of 200 species of viruses (Dyakonov 2000). Some of the viruses cause huge crop losses in many crops. Cereal aphids such as $R h$. padi are widely known vectors of many viruses such as Barley yellow dwarf virus (BYDV), Potato virus Y (Y), etc. (Insert reference).

More than 70 aphids species - vectors of potato viruses are known (Warren et al. 2005; Pelletier et al. 2012). Among them, there are species colonizing potatoes, and those that do not colonize but contact with plants in case of accidental landing during the resettlement. In the NorthWestern region, six species of aphids, that live on potatoes and can transfer the persistent and non-persistent viruses are found out, i.e. Aphis fabae Scop., Myzus persicae Sulz., Macrosiphum euphorbiae Thomas, Aulacorthum solani Kalt., Aphis nasturtii Kalt., Aphis frangulae Kalt. (Anisimov 2010; Berim 2017; Fominykh et al. 2017). Brevicoryne brassicae L., Sitobion avenae F., M. cerasi F., Rhopalosiphum padi (L.), Brachycaudus helichrysi Kalt., Metopolophium dirhodum Walk and others do not colonize potatoes, but transfer non-persistent viruses over probing
(Berim 2017; Sozonov 2005; Fox et al. 2017). During migration flight, the number of the last group of aphids in agroecosystems can be quite high followed by increased plant infection by viruses, and their significance in infection of plants increases (Dyakonov 2000; Warren et al. 2005). It is accepted that viruses can be carried by both imago, and nymphs of winged and apterous morphs of aphids (Vlasov and Larina 1982; Miloševic et al. 2014). The winged morphs are the main virus vector to potato plants, regardless of being or not a host plant.

According to Finlay and Luck (2011), the primary hosts for $R h$. padi is $P$. avium in Europe, while $P$. virginiana L., and $P$. pensylvanica Loisel are in North America; other plants of 110 species from 7 families are indicated as secondary hosts. The full life cycle of $R h$. padi includes some stages. Aphids overwinter as eggs on primary host. In spring, overwintered eggs hatch into fundatrices. Rh. padi reproduces only by viviparous parthenogenesis until the autumn, when sexual reproduction takes place. On the bird cherry, the aphids pass through 3-4 generations. There are apterous and alate individuals (emigrants) migrating to secondary hosts among the descendants on primary host. The emigrants give rise to further alate and apterous offspring on summer hosts. Remigrants (gynoparae and males) return from the secondary hosts to primary ones in autumn. On the primary hosts, gynoparae produce the nymphs of sexual females (oviparae), which lay wintering eggs after encountering with males (Williams and Dixon 2007).

The intensity of migration of aphids and the transmission of viruses depends on the factors that 
determine wing formation and flight behavior. Wing polymorphism and polyphenism are seen in the majority of Hemiptera species (Ogawa and Miura 2014). In the case of polymorphism, aphids exhibit only apterous (fundatrices, oviparae), or strictly alate (males, gynoparae) morphs. In polyphenism, development pathways leading to alternative phenotypes depending on surrounding conditions such as combination of endogenous (epigenetic) factors (intraspecies variability, morph and age of mother, generation) and exogenous ones (quality of host plants, density of colonies, photoperiod, temperature) (Ogawa and Miura 2014; Vereschagina and Gandrabur 2014). It is still unknown the extent to which entomophagous can affect the flying activity of aphids. They reduce the aphids abundance and number of alate individuals in their offspring, and can cause the effect of "pseudo-crowding" increasing the wing formation on the other hand (Kunert et al. 2005). The development of asexual alate in $R h$. padi populations are known to be associated with host plant quality (Müller 2001; Williams and Dixon 2007; Parry 2013; Vereschagina and Gandrabur 2014). The interrelation in the aphid migration with the bird cherry development is always observed. Usually it starts during the period of mass flowering of the bird cherry and lasts to the beginning of fruiting (Vereschagina and Gandrabur 2016).

There are three waves of flight in the life cycle of heteroecious species of aphids: spring, summer, and autumn. Spring and autumn flights are associated with long-distance migrations, and summer one characterized by flight to small distances. The activity of virus transmission to host and non-host plants is most dangerous during their spring host alternation. Emigrants appear in the ontogenesis of heteroecious populations of aphids according to their genetic program of host change (Glinwood and Pettersson 2000). The bird cherry-oat aphid Rhopalosiphum padi (L.) is one of the most widespread species of cereal aphids in the North-Western region of Russia, which is encountered in the fields annually. During the periods of mass flight, it has been noted as a carrier of PVY in various countries in a long time (Close and Lamb 1961; Berim 2017; Mayer 2017).

The purpose of our study is to specify the characteristic features on the development of $R h$ padi, associated with wing formation, dynamics of flight activity, settling behavior and transmission of non-persistent viral infection to host (wheat) and non-host (potatoes) plants.

\section{MATERIALS AND METHODS}

Long-term studies (2000-2017 years) were carried out using Rh. padi as an example. This species is holocyclic and heteroecious in North-West of Russia. We monitored the clonal structure and flight of aphids' emigrant in the environs of St. Petersburg and in the Leningrad Province. The beginning and the end of emigration were recorded in 15 wild trees of bird-cherry Padus avium Mill. Growing in these regions. Surveys were carried out 2-3 times a week, since the end of April. For this purpose, after the appearance of alatoid fourth instar nymphs, isolating cover was placed on the shoots with $R h$. padi colonies, and the appearance of the first emigrant females was recorded.

The seasonal dynamics of $R h$. padi abundance on bird cherry was studied in March-June 2017 on three wild trees growing in Pushkin (a district of St. Petersburg). The eggs and aphids were counted on 100 annual shoots, first on the buds and later on the whole surface. The shoots were randomly selected from all the crown layers and labeled. The first survey was performed before the hatching of fundatrices, and the last one, after the completion of emigration. Altogether, 12 surveys were carried out with intervals of 6-10 days. The number of aphids was recalculated for 10 buds, and later, for 10 shoots.

The behavior of Rh. padi during the secondary host selection was studied in emigrants from different clones which were collected off bird cherry $12-14 \mathrm{~h}$ after their imaginal molt, before the beginning of emigration flight. This study was performed in 2006-2013 and included several experiments. The series studied in the consecutive years comprised 22, 24, 24, 43, 36, 32, 26, and 23 aphids. The emigrants were placed singly in vegetative pots with gauze covers, containing shoots of Leningradskaya 6 wheat variety. Mortality, settlement, and the timing of reproduction of the aphids were recorded for 4 days.

The behavior of $R h$. padi emigrants collected off bird cherry before flight, during contact with non-host plants was studied using two potato varieties with different levels of resistance to PVY: Charodey (virus resistance -VR) and Nevsky (virus medium resistance - VMR) (Sozonov 2005). The tests involved 10 plants of each variety at the early flowering stage, which had been grown in the field and then replanted into individual pots with isolating covers. The bird cherry shoots with aphid emigrants were also covered with isolating bags and then cut off the trees. Emigrants were collected from bird cherry shoots into small glass containers (200 aphids in each) using an aspirator, and the containers were immediately placed in the pots with potato plants under isolating covers. Observation of aphids was carried out daily until the insects become perished. The aphids were counted during visual examination, if necessary, the isolating covers were carefully removed and then replaced.

The abundance of alate virginoparae in the offspring of emigrants of different $R h$. padi clones and the timing of their appearance were studied in 2000-2017. No less than 20 clones were tested in 3 replicates every year. The emigrants were removed from bird cherry trees from 6 local populations in St. Petersburg and Leningrad Province. The secondary host plant was spring wheat [Triticum aestivum L. var. lutescens (Alef.) Mansf.] at the early tillering phase, first of Leningradka variety and starting with 2012, of Leningradskaya 6 variety. Emigrants were placed singly in containers with 10 wheat plants in each and with isolating gauze covers. Each clone was represented by 3 emigrants; 30 containers were populated with aphids from 10 clones every day. The total number of aphids in the offspring and the number of alate virginoparae were determined 14 days after the onset of reproduction. 
Aphids in the experiments developed at $20-26^{\circ} \mathrm{C}$ and the natural photoperiod.

The meteorological data describing the environmental conditions during the 12 years of research are borrowed from the sites http://weatherarchive.ru (temperature) and http://www.pogodaiklimat.ru (precipitation=rainfall). Some meteorological parameters that are particularly important for analysis of the effect of weather conditions on the aphid flight are given in Table 1.

The results were statistically processed with ANOVA using Statistica and R software. The influence of weather conditions on $R h$. padi flight was assessed by linear correlation analysis.
To study the effect of the density of emigrant colonies on the appearance of alate forms in the offspring, the combined results for all the years of research were ranked into 3 classes according to the offspring abundance, and the data were used in ANOVA.

\section{RESULTS AND DISCUSSION}

\section{Results}

Our data have demonstrated variation in the timing and duration of $R h$. padi flight in North-West Russia in different years (Figure 1).

Table 1. Selected meteorological data characterizing the years of research

\begin{tabular}{|c|c|c|c|c|c|c|c|c|c|c|c|c|}
\hline \multirow{3}{*}{ Year } & \multirow{3}{*}{ Month } & \multicolumn{6}{|c|}{ Air temperature, ${ }^{\circ} \mathrm{C}$} & \multicolumn{5}{|c|}{ Rainfall, mm } \\
\hline & & \multicolumn{3}{|c|}{ Decade } & \multirow{2}{*}{$\begin{array}{l}\text { Max. } \\
\text { (date) }\end{array}$} & \multirow{2}{*}{$\begin{array}{c}\text { Min. } \\
\text { (date) }\end{array}$} & \multirow{2}{*}{$\begin{array}{c}\text { Averageo } \\
\text { fmonth }\end{array}$} & \multicolumn{3}{|c|}{ Decade } & \multirow{2}{*}{$\begin{array}{c}\text { Max } \\
\text { (date) }\end{array}$} & \multirow{2}{*}{ Total } \\
\hline & & $\mathbf{I}$ & II & III & & & & I & II & III & & \\
\hline \multirow[t]{3}{*}{2008} & April & 7.7 & 4.2 & 9.4 & $22.0(30)$ & $-3.0(23)$ & 7.1 & 12.1 & 31.2 & 0.0 & $16.9(11)$ & 43.3 \\
\hline & May & 12.1 & 8.5 & 12.1 & $23.0(2)$ & $1.0(16)$ & 10.9 & 0.8 & 16.5 & 1.4 & $10.5(18)$ & 18.7 \\
\hline & June & 13.6 & 15.6 & 16.1 & $24.0(20)$ & $6.0(9)$ & 15.1 & 21.8 & 22.8 & 25.3 & $10.7(11)$ & 69.9 \\
\hline \multirow[t]{3}{*}{2014} & April & -0.3 & 5.7 & 8.7 & $20.0(21)$ & $-6.0(2)$ & 4.7 & 3.9 & 4.8 & 1.0 & $3.0(6 ; 14)$ & 9.7 \\
\hline & May & 6.4 & 13.4 & 16.5 & $25.8(20)$ & $-1.0(3)$ & 12.1 & 14.0 & 13.7 & 64.7 & $32.0(28)$ & 92.4 \\
\hline & June & 17.7 & 12.3 & 12.0 & $30.0(6)$ & $4.0(18)$ & 14.0 & 21.4 & 25.6 & 24.1 & $20.0(30)$ & 71.1 \\
\hline \multirow[t]{3}{*}{2016} & April & 4.9 & 5.3 & 7.4 & $18.0(28)$ & $-4.0(4)$ & 5.9 & 8.0 & 26.3 & 34.6 & $12.0(29)$ & 68.9 \\
\hline & May & 13.9 & 11.1 & 14.6 & $18.3(6)$ & $3.0(12)$ & 13.2 & 0.0 & 2.3 & 28.0 & $15.0(27)$ & 30.3 \\
\hline & June & 12.5 & 14.7 & 18.5 & $27.0(26)$ & $4.0(7)$ & 15.2 & 11.8 & 57.4 & 21.9 & $28.0(16)$ & 91.1 \\
\hline \multirow[t]{3}{*}{2017} & April & 4.6 & -0.2 & 4.4 & $15.0(10)$ & $-9.0(19)$ & 2.9 & 12.8 & 18.1 & 55.2 & $15.0(23)$ & 86.1 \\
\hline & May & 5.6 & 9.8 & 12.6 & 24.0 (19) & $-2.0(10)$ & 9.3 & 1.0 & 1.1 & 11.3 & $7.0(31)$ & 13.4 \\
\hline & June & 11.4 & 15.2 & 14.1 & $24.4(17)$ & $3.4(2)$ & 13.6 & 17.6 & 26.3 & 24.6 & $13.0(21)$ & 68.5 \\
\hline
\end{tabular}

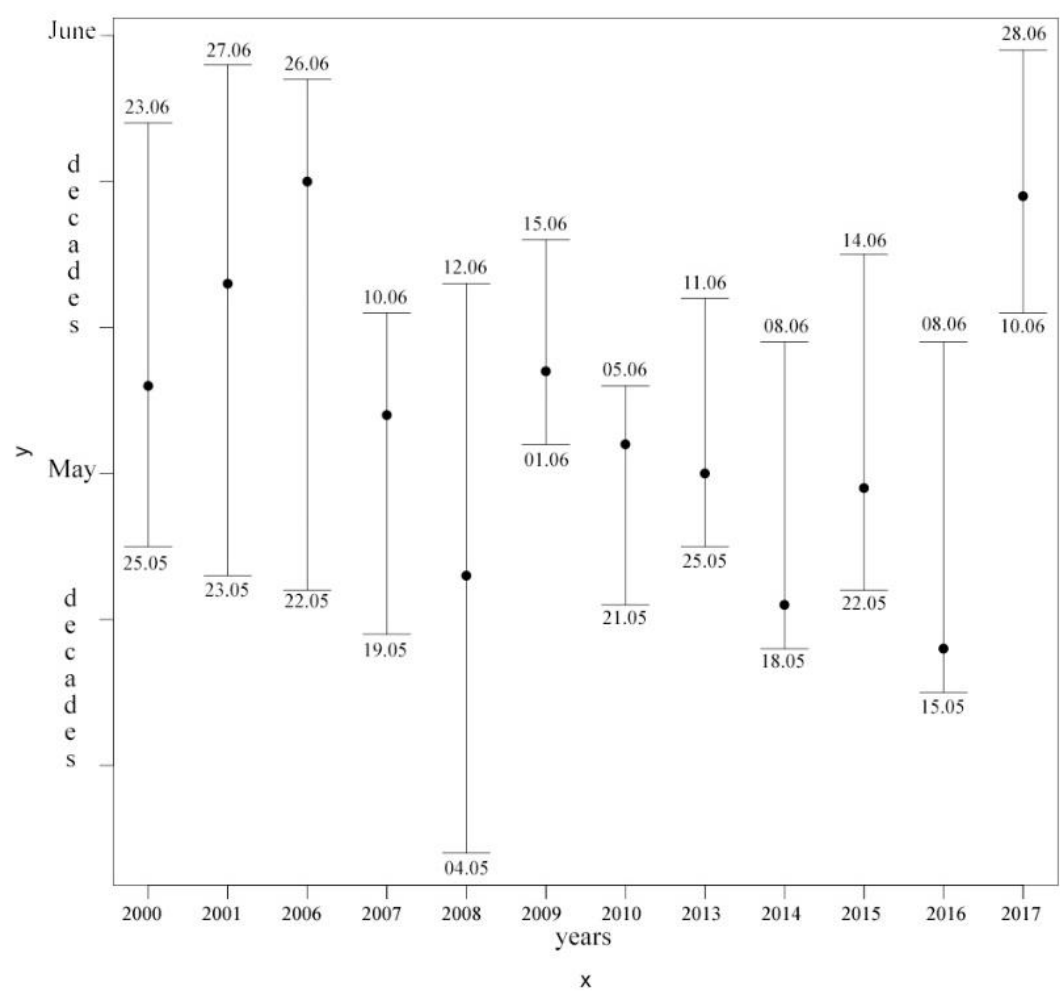

Figure 1. Timing of flight of Rh. padi in North-West Russia. Note: Dots mark the beginning of mass flight of emigrants; numbers on the top and on the bottom are means the dates 


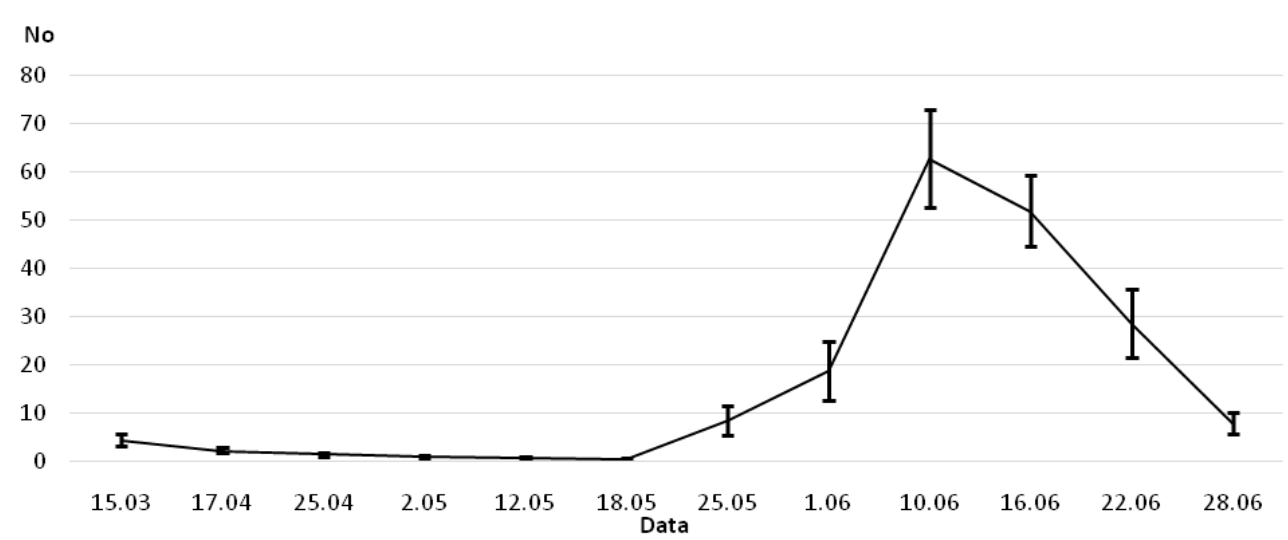

Figure 2. Seasonal changes in the abundance of $R h$. padi feeding on $P$. avium in 2017. Note: No. is the number of aphids per 10 buds (first) or 10 shoots (later)

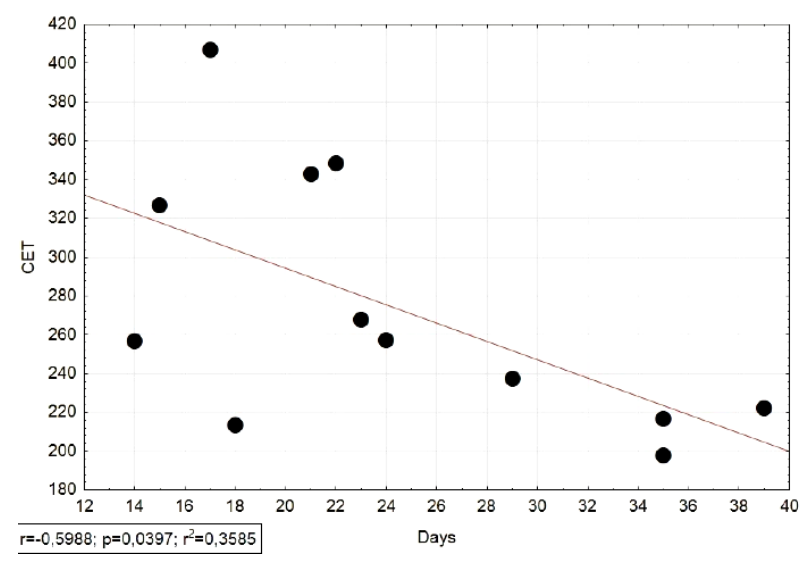

Figure 3. Correlation between the starting date and duration of $R h$. padi flight: elevated CET for the middle and last thirds of May and the first of June vs. duration of aphid flight for the 12 years of research

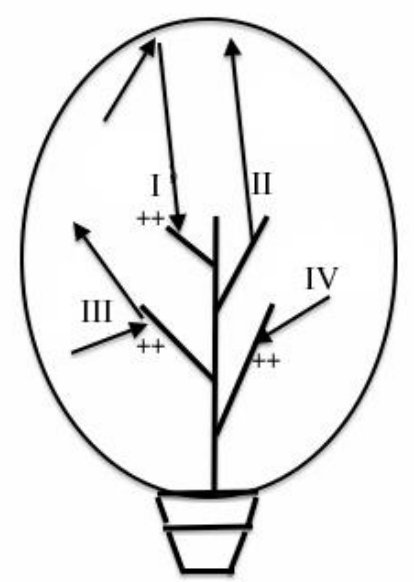

Figure 4. Differences in the behavior of four groups of emigrants on the secondary host plant. Note: Arrows show the direction of flight; crosses mark the places of settlement
The earliest onset of Rh. padi flight for the whole study period was observed on May 4, 2008; the latest, on June 10,2017 . In other years, the flight duration was 17-39 days (Figure 1).

Correlation analysis was used to estimate the relations between the cumulative effective temperatures (CET) for the beginning and middle thirds of April and the duration of the period before the onset of aphid flight in May and also between the CET for the middle and last thirds of May and the beginning first of June and the total flight duration (Figure 3). The sums were calculated relative to $\mathrm{T}_{\text {base }}=4.5^{\circ} \mathrm{C}$ (Bokina 2009). Similar calculations were performed for the total rainfall $(\mathrm{RF}, \mathrm{mm})$ during the same periods. The strong negative correlation was observed between the CET for the middle and last thirds of May and the beginning first of June and the total duration of $R h$. padi flight (Figure 3).Elevated CET displayed a decreasing trend in duration of aphid flight $\left(\mathrm{R}^{2}=0.36\right)$. There were no statistically significant correlations in other variants.

After leaving the primary host, emigrants of $R h$. padi never return onto it (Glinwood and Pettersson 2000). By contrast, the response of emigrants to transfer onto the secondary host $12-16 \mathrm{~h}$ after imaginal molt was found to be less uniform. In nature, a similar situation may occur when aphids are shaken off the primary host by wind or rain.

The emigrants collected from bird cherry before flight could be divided into 4 groups differing in their trophic and reproductive behavior on the optimal secondary host (cv. Leningradskaya 6). In particular, aphids of the 1st group started feeding and reproducing immediately after transfer; aphids of the 2nd group started feeding and reproducing after 1-4 days of repeated take-offs and moving around the container; aphids of the 3rd group produced 6-8 larvae, then flew away and eventually died on the container wall; aphids of the 4th group left the host without reproducing and died within 4 days (Figures $4 ; 5$ ). 


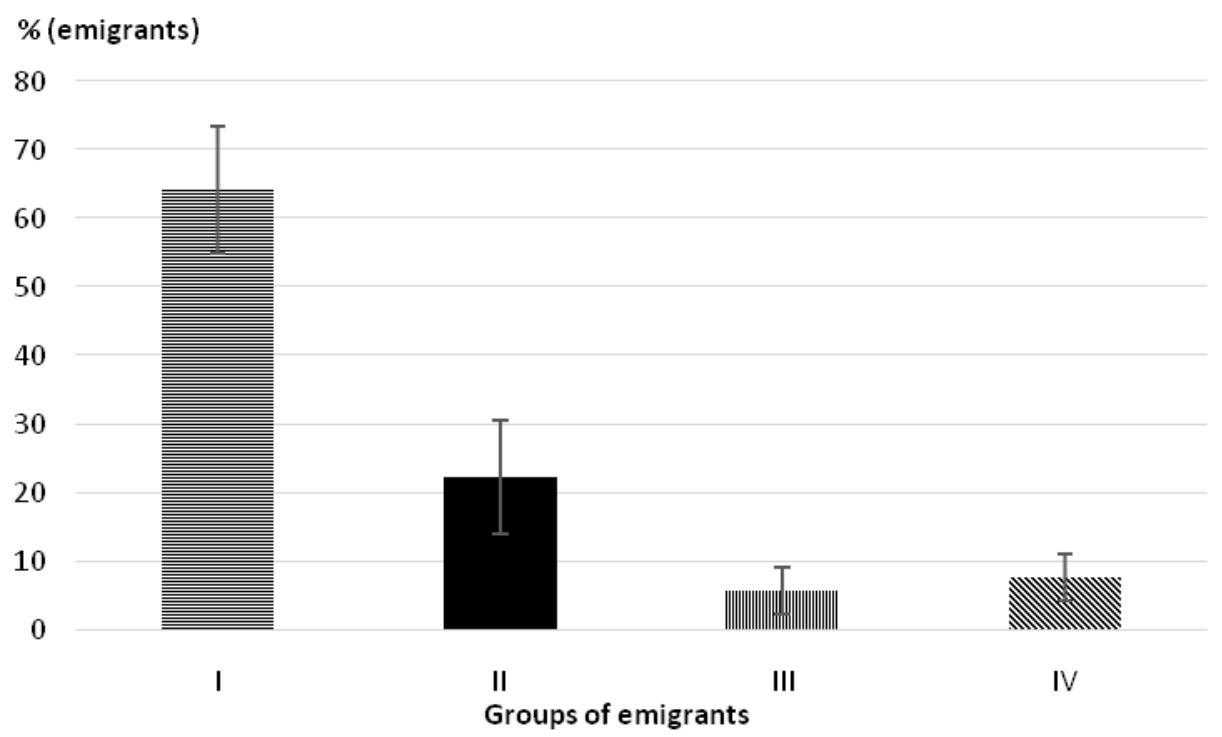

Figure 5. Relative number (\%) of emigrants in groups with different behavior patterns. Note: means \pm SD

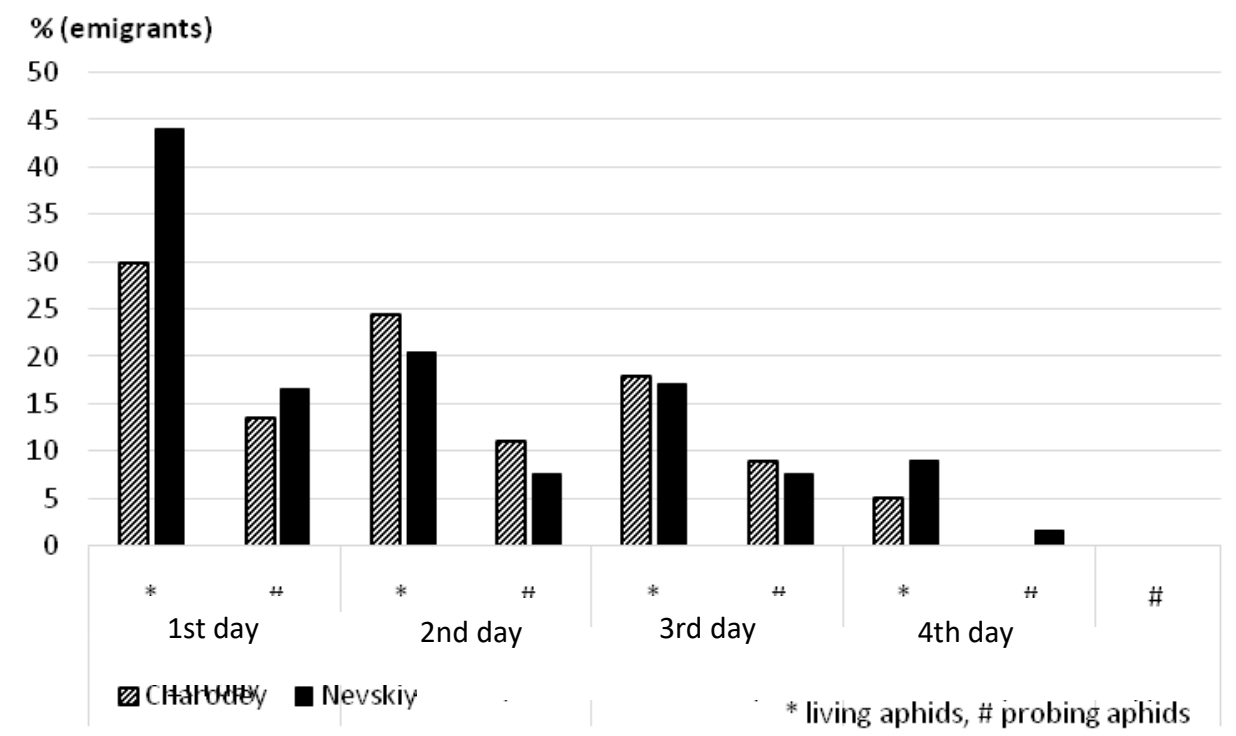

Figure 6. Survival and probing behavior of Rh. padi emigrants on potato plants

The interaction of $R h$. padi emigrants with non-host plants were studied by the example of two potato varieties differing in the level of resistance to PVY (Figure 6).

All the aphids died within 4 days on both potato varieties, and no larvae were found. Survival of emigrants during the first day was higher on Nevsky than on Charodey variety; besides, probing behavior on Nevsky variety was observed during all the 4 days, 1 day longer than on Charodey variety. Aphids mostly moved and probed on the abaxial (lower) leaf surface, rarely on the adaxial (upper) surface or on the stem.

Analysis of the number of alate females in the 1stgeneration offspring produced by emigrants in 2000-2017 showed that the timing and intensity of aphid dispersal on the secondary host varied depending on the clonal composition (Table 2). The first colonies are most often formed by reproduction of a single emigrant. Aphids usually become ready to disperse 2 weeks after the beginning of emigrant reproduction, when alate migrant females appear in the colonies.

The percentage of clones represented by emigrants that had no alate individuals in the 1 st generation of their offspring varied from year to year (Table 2). Such clones were absent in 2004 when the density of the offspring colonies was the highest, but they were present in considerable numbers in 2008 and 2009 when the offspring density was low. In the seasons with the highest rates of emigrant reproduction (2000 and 2004), the 1st-generation offspring of some clones included $20-30 \%$ and more alate females. 
Table 2. Colony density and the fraction of Rh. padi clones represented by emigrants with different numbers of alate individuals in the 1st-generation offspring

\begin{tabular}{llcccc}
\hline \multirow{2}{*}{ Year } & \multirow{2}{*}{ CD } & \multicolumn{3}{c}{ Proportion (\%) of $\boldsymbol{R h}$. padi clones with different number (\%) of alate offspring } \\
\cline { 3 - 6 } & & $\mathbf{0}$ & less 10 & $\mathbf{1 0 - 2 0}$ & $\mathbf{2 1 - 3 0}$ \\
\hline 2000 & $1984.9 \pm 269.0$ & 10.0 & 77.5 & 12.5 & 0 \\
2001 & $632.8 \pm 94.0$ & 60.0 & 40.0 & 0 & 0 \\
2002 & $469.3 \pm 9.8$ & 30.0 & 70.0 & 0 & 0 \\
2003 & $497.6 \pm 60.0$ & 80.0 & 20.0 & 0 & 0 \\
2004 & $2095.2 \pm 330.0$ & 84.0 & 90.9 & 0 & 0.1 \\
2005 & $595.3 \pm 77.0$ & 33.3 & 16.0 & 0 & 0 \\
2006 & $1154.7 \pm 185.3$ & 36.7 & 66.7 & 0 & 0 \\
2007 & $632.3 \pm 43.9$ & 93.1 & 63.3 & 0 & 0 \\
2008 & $419.6 \pm 43.9$ & 91.7 & 6.9 & 0 & 0 \\
2009 & $321.8 \pm 40.5$ & 57.1 & 8.3 & 0 & 0 \\
2010 & $595.4 \pm 56.0$ & 15.1 & 42.9 & 0 & 0 \\
2011 & $617.5 \pm 58.7$ & 65.0 & 34.9 & 0 & 0 \\
2012 & $475.9 \pm 87.0$ & 50.0 & 55.0 & 0.0 & 0 \\
2013 & $746.1 \pm 113.0$ & 73.3 & 26.7 & 0 \\
2014 & $512.9 \pm 53.5$ & 76.5 & 23.5 & 0 & 0 \\
2015 & $473.2 \pm 44.9$ & 75.0 & 25.0 & 0 & 0 \\
2016 & $585.6 \pm 67.0$ & 30.0 & 70.0 & 0 \\
\hline
\end{tabular}

Note: $\mathrm{CD}$ - colony density (crowding) = number of aphids per 10 plants; means $\pm \mathrm{S} \overline{\mathrm{x}}$

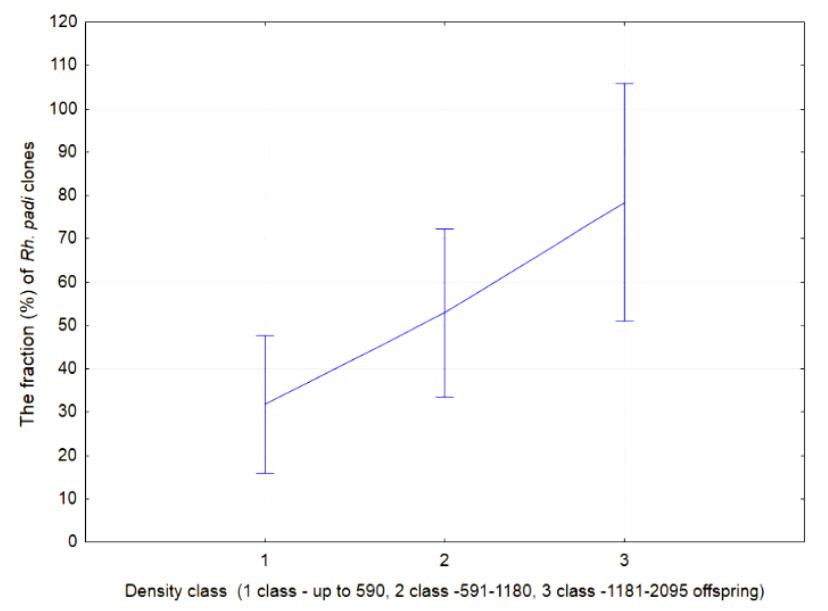

Figure 7. The fraction (\%) of Rh. padi clones whose 1-st generation offspring included less than $10 \%$ of alate females, in relation to the density (crowding) of colonies

The ANOVA results revealed a considerable effect of colony density on the appearance of alate females in the 1st-generation offspring of emigrants in groups of $R h$. padi clones (Figure 7).

\section{Discussion}

The appearance of flying aphids depends both on the abundance and crowding level of the colonies and on the environmental conditions suitable for taking off and maintaining flight. These conditions include the temperature, precipitation, wind velocity, photoperiod, and the host plant quality, and constitute a complex of parameters that is species- and region-specific (Parry 2013).
According to our data, the flight of emigrants in NorthWest Russia usually starts in the second half of May and ends in the middle or last third of June (Figure 1). Very warm and fairly dry weather in April and May of 2008 facilitated the earliest onset of $R h$. padi flight (Table 1). The mean temperatures of these two months were $+7.1^{\circ} \mathrm{C}$ and $+10.9^{\circ} \mathrm{C}$ while the long-term mean values are $+4.4^{\circ} \mathrm{C}$ and $+9.8^{\circ} \mathrm{C}$, respectively. The total rainfall in April 2008 was $43.3 \mathrm{~mm}$ but most of the rainfall occurred during 2 days in the middle third of that month $(16.9 \mathrm{~mm}$ on April 11 and $11.1 \mathrm{~mm}$ on April 14). The total rainfall in May 2008 was $18.7 \mathrm{~mm}$, considerably less than the long-term mean of $38 \mathrm{~mm}$. The early flight of aphids could also have been triggered by the steep rise of temperature from $0^{\circ} \ldots$ $3^{\circ} \mathrm{C}$ on April 20,21 , and 23 to $+23.0^{\circ} \mathrm{C}$ on May 2. The flight of $R h$. padi in 2008 was also the longest (39 days) for the whole study period (Figure 1). The latest and shortest flight was observed in 2017 (Figure 1); it took place in cold and rainy weather the like of which had not been recorded in the past 20 years (Table 1). The rainfall and snowfall in April 2017 in St. Petersburg and Leningrad Province amounted to $263 \%$ of the long-term mean precipitation (http://www.meteo.nw.ru; https://www.gismeteo.ru). In such weather, the growth of $R h$. padi colonies on bird cherry were slow (Figure 2) while the emigrant flight started at the peak of their abundance and lasted only 18 days (Figure 1).

Over the years of research, mass flight of aphids was usually observed close to the middle of the whole flight period (Figure 1). However, in 2014 and 2016 the peak was reached already 2 days after the onset of flight (on May 21 and May 18, respectively), although the flight periods were not too short: 21 and 24 days, respectively. Heavy showers in the last third of May 2014 (Table 1) shifted the flight peak closer to its starting date (Figure 1), probably due to a 
decrease in the total number of flying aphids. Abundant rainfall in the middle and last thirds of April and very dry weather in the middle and last thirds of May 2016 (Table 1) also affected the flight dynamics and probably shifted the peak off its typical position (Figure 1). Despite these examples, the most pronounced of the observed trends were weak and still not highly significant negative correlation between the timing of $R h$. padi flight in May and the CET value for the first two-thirds of April $(\mathrm{r}=0.42$; $\mathrm{p}=0.16$ ); this is the period when the fundatrices hatch and develop to adults (Vereschagina and Gandrabur 2016).

Wiktelius (1984) was among the first researchers to note the absence of correlation between the spring temperatures and the earliest dates of capture of $R h$. padi emigrants. No more than 4 fundatrigenous generations can develop on bird cherry. It is supposed that the first emigrants may appear in the offspring of the 1st or 2nd fundatrigenous generation of $R h$. padi, depending on the colony density: earlier at high densities and later at low densities (Wiktelius 1984; Glinwood and Pettersson 2000). However, the latter mechanism may work only during mass flight, because some clones in our material contained the first emigrants already among the initial (first-day) offspring of the fundatrices (Vereschagina 2017), when neither "crowding effect" nor changes in the leaf quality could influence the production of alate emigrants and their flight. The greatest fraction of emigrants was recorded in the offspring of the 1st generation of fundatrigenous females (i.e., in the $2^{\text {nd }}$ fundatrigenous generation) (Vereschagina 2017). Thus, the timing of appearance of emigrants and their flight is clone-specific (polymorphism), rather than determined by the colony density or the host quality; at the same time, the number of emigrants during the subsequent colony development also depends on the crowding level, the decreasing growth rate of the host plant, the weather conditions, and the specific details of the clones' response to these factors (polyphenism).

A strong positive correlation was observed between the duration of the aphid flight and the CET value for the middle and last thirds of May and the first of June (Figure 3). It is well known that higher temperatures (within the developmental norms) lead to a rapid increase in the density and crowding of aphids and, therefore, to higher total abundance and extension of the flight period.

The influence of precipitation on the flight of aphids is still poorly studied, and the relevant literature data are scanty (Parry 2013). Precipitation may affect the take-off and flight proper, and also reproduction and polyphenism of aphids. However, we did not reveal significant correlations between the precipitation and the timing of emigrant flight of $R h$. padi.

Transmission of viruses closely depends not only on the number of flying aphids but also on the patterns of their behavior during flight and host-seeking. Aphids have complex flight behavior determined by biological motivations, i.e., an intrinsic program that may be modified by environmental factors (Eryomenko and Burikov 2004; Pavlyushin et al. 2015; Moericke 1955; Döring 2014). Researchers differentiate between long-distance (migration) flight related to transition of aphids between the primary and secondary hosts in spring and autumn, and short-distance (trivial) flights characteristic of their summer dispersal (Robert 1987; Irwin et al. 2007; Döring 2014). According to the generally accepted model of Moericke (1955), the behavior associated with the migration flight includes 4 stages: the teneral period and take-off; the "soaring" migration flight; the attacking flight related to distant detection of host plants; selection of the feeding site on the plant using contact and gustatory cues. The first two stages have the migrational motivation, and the last two, the trophic motivation. The behavior of summer migrants during the trivial flight comprises the same stages except for the "soaring" flight. An aphid makes the migration flight only once in its life but it can perform several trivial flights after or independently of the migration flight (Parry 2013).

Aphids that have emigrated from bird cherry trees can get onto host or non-host plants. The behavior of emigrants on host plants was not uniform. Most of Rh. padi emigrants $(64.2 \pm 9.3 \%)$ transferred from bird cherry $12-14 \mathrm{~h}$ after the imaginal molt started feeding and reproducing; these aphids moved over the plant without flying (Figure 5), therefore they were not motivated to fly before changing their trophic preferences. A considerably smaller fraction of emigrants needed a short flight before settling (22.3 \pm $8.2 \%)$. The remaining emigrants either started reproducing, then flew away and died $(5.8 \pm 3.5 \%)$, or died before the onset of reproduction $(7.7 \pm 3.4 \%)$. As a rule, emigrants of all the groups probed the plant surface; therefore, these aphids, especially those motivated to disperse, could transmit nonpersistent viruses during repeated flights.

Emigrants transferred onto a non-host plant (potato) repeatedly probed the plant tissue with their stylets for several minutes, then flew to a different place and probed again, this behavior being quite conspicuous. Alate aphids have a fairly limited time for choosing the host plant. It is known that within not more than 4 days after the imaginal molt, the flight muscles of many species are autolyzed to compensate for the energy loss during migration and to support reproduction (Dixon 1998). The absence of offspring clearly showed that potato plants were generally unsuitable for $R h$. padi feeding, but we did reveal some minor differences in the survival of aphids on the two potato varieties (Figure 6). Thus, emigrants could not survive for more than 4 days on a non-host plant but some of them probed the plants and could act as sources or vectors of nonpersistent viral infection. It may be supposed that emigrants supported themselves by consuming certain amounts of xylem sap; this is known to occur in some aphid species feeding on unfavorable hosts, including potato plants (Pompon et al. 2010).

Having settled on the secondary host, emigrants start reproducing. The appearance of alate dispersal migrants, especially in windy weather, is directly relevant to virus transmission. Wing polyphenism in the summer aphid generations is believed to be largely determined by crowding and the host quality (Williams and Dixon 2007): more alate individuals are produced at high density of the maternal generation and under worsening trophic conditions. However, the crowding effect may be less 
important for the aphid species that do not form dense colonies, such as Myzus persicae Sulz. (Williams and Dixon 2007). Considering the significant maternal influence on the offspring, one might expect that emigrants would produce a considerable fraction of alate. However, the 1st-generation offspring of emigrants is usually apterous (Vereschagina and Shaposhnikov 1998; Williams and Dixon 2007). Longer studies revealed some differences between groups of clones in the production of alate in the 1st generation of emigrants feeding on favorable secondary hosts in different years. During all the years of study (except 2004), we observed some clones that had no alate in the offspring of emigrants, and also clones in which alate comprised less than $10 \%$ of the offspring (Table 2). Clones with high reproduction rates were observed only in some years. The exact reasons for appearance of such clones remain unknown. As a result of crowding, the 1stgeneration offspring of these clones included 20-30\% and more alate. Probably as the result of cold spring with unusually abundant precipitation, in 2017 the fraction of clones with alate in the 1 st-generation offspring was as great as $70 \%$. On the whole, the fraction of clones with alate in the 1st-generation offspring was significantly positively correlated with the colony density (Figure 7). Thus, the appearance of alate in the 1st-generation offspring of emigrants is a clone-specific trait and also depends on the crowding level.

As a result of the long-term study of emigration of $R h$. padi from bird cherry, the behavior of emigrants during host selection, and production of the first alate offspring after settling on the secondary host, we can draw the following conclusions.

In conclusion, the flight of $R h$. padi emigrants in the North-West of the species range usually starts in the second half of May, but not earlier than May 4 and not later than June 10. The flight duration is 17-39 days. Weather conditions (temperature and precipitation) affect the timing of emigration; there was a statistically significant negative correlation between the CET value for the middle and last thirds of May and the first of June and the duration of emigrant flight. The production of the earliest emigrants, and also the earliest alate migrant in their offspring is clone-specific. The percentage of fraction clones with alate in the 1st-generation offspring of emigrants was shown to increase with the density of the filial generation. The behavior of $R h$. padi emigrants during host selection varied depending on the presence of long-distance flight motivation. The emigrants displayed flight and probing behavior both on host (wheat) and on non-host (potato) plants. Such behavior may continue for up to 4 days and may lead to transmission of nonpersistent viruses onto the visited plants. These data are important for improving the control of aphids that transmit viruses.

\section{ACKNOWLEDGEMENTS}

The study was financially supported by the Russian Science Foundation (Project 16-16-04079).

\section{REFERENCES}

Anisimov BV. 2010. Viral diseases and their control in potato seed production. Prot Quarantine Plants 5: 12-18.

Berim MN. 2017. Aphids are potato pests. Prot Potato 1: 30-34.

Bokina IG. 2009. Cereal aphids and their entomophages in the foreststeppe of Western Siberia. Novosibirsk. 182 p.

Close R, Lamb KP. 1961. Trapping study of some winged aphid vectors of plant virus diseases in Canterbury, New Zealand. N Z J Agric Res 4: 606-618. DOI: 10.1080/00288233.1961.10431618

Dixon AFG. 1992. Constraints on the rate of parthenogenetic reproduction and pest status of aphids. Invertebr Reprod Develop. 22: 159-163. DOI: $10.1080 / 07924259.1992 .9672268$

Dixon AFG. 1998. Aphid Ecology / 2ndedn. Chapman and Hall, London.

Döring TF. 2014. How aphids find their host plants, and how they don't. Ann Appl Biol 165: 3-26. DOI: 10.1111/aab.12142

Dyakonov KP. 2000. Insect as a factor of dissemination of phytopathogenic viruses on the Russian Far East. A. I. Kurentsov Ann Meml Meet. Biology-and-soil Institute of Far-Eastern Division of the Russian Academy of Science, Vladivostok. XI. P.15-26. http://ibss.febras.ru/Files/KUR/00001218.pdf

Eryomenko EA, Burikov AA. 2004. The role of motivation in the behavior. Adv Curr Nat Sci 10: 29-30. https://www.naturalsciences.ru/pdf/2004/10/8.pdf

Finlay KJ, Luck JE. 2011. Response of the bird cherry-oat aphid (Rhopalosiphum padi) to climate change in relation to its pest status, vectoring potential and function in crop-vector-virus pathosystem. Agricult Ecosyst Environ 144: 405-421. DOI: 10.1016/j.agee.2011.08.011

Fominykh TS, Ivanova GP, Medvedeva KD. 2017. Monitoring of viral diseases of potato in the Pskov and Astrakhan regions of Russia. Ann Plants Prot 4 (94): 29-34.

Fox A, Collins LE, Macarthur R, Blackburn LF, Northing P. 2017. New aphid vectors and efficiency of transmission of Potato virus $\mathrm{A}$ and strains of Potato virus Y in the UK. Plant Pathol. 66 (2): 325-335. DOI: $10.1111 /$ ppa.12561

Glinwood R, Pettersson J. 2000. Host choice and host leaving in Rhopalosiphum padi (Hemiptera: Aphididae) emigrants and repellency of aphid colonies on the winter host. Bull Entomol Res 90: 57-61.

Irwin ME, Kampmeier GE, Weisser WW. 2007. Aphid Movement: Process and Consequences. In van Emden HF, Harrington R (eds.) Aphids as Crop Pests. CABI, Wallingford, United Kingdom.

Kunert G, Otto S, Röse USR, Gershenzon J, Weisser WW. 2005. Alarm pheromone mediates production of winged dispersal morphs in aphids. Ecol Lett 8: 596-603. DOI: 10.1111/j.14610248.2005.00754.x

Mayer MC. 2017. Early detection of virus infections in potato by aphids and infrared remote sensing. Department of Crop Production Ecology, Faculty of Natural Resources and Agricultural Sciences, Swedish University of Agricultural Sciences, Uppsala, Sweden.

Miloševic D, Milenkovic S, Peric P, Stamenkovic S. 2014. The effects of monitoring the abundance and species composition of aphids as virus vectors on seed potato production in Serbia. Pestic. Phytomed. (Belgrade). 29 (1): 9-19. DOI: 10.2298/PIF1401009M

Moericke V. 1955. Über die Lebensgewohnheiten der geflügelten Blattläuse (Aphidina) unterbesonderer Berücksichtigung des Verhaltensbeim Landen. Zeitschriftfür Angewandte Entomologie 3: 29-91. DOI: 10.1111/j.1439-0418.1955.tb00775.x

Müller CB, Williams IS, Hardie J. 2001. The role of nutrition, crowding and interspecific interactions in the development of winged aphids. Ecol Entomol 26: 330-340

Ogawa K, Miura T. 2014. Aphid polyphenisms: trans-generational developmental regulation through viviparity. Front Physiol 5 (1). DOI: 10.3389/fphys.2014.00001

Parry HR. Cereal aphid movement: general principles and simulation modeling. Movement Ecol 14 (1): 3-15. DOI: 10.1186/2051-3933-114

Pavlyushin VA, Vilkova NA, Sukhoruchenko GI, Nefedova LI, Kapustkina AV. 2015. Sun pest and other grain bugs/ SPb: GNU VIZR. All-Russian Research Institute of Plant Protection. St Petersburg.

Pelletier Y, Nie X, Giguére MA, Nanayakkara U, Maw E, Foottit R. 2012. A new approach for the identification of aphids vectors (Hemiptera: 
Aphididae) of Potato virus Y. J Econ Entomol 105 (6): 1909-1914. DOI: 10.1603/EC12085

Pompon J, Quiring D, Giordanengo P, Pelletier Y. 2010. Role of xylem consumption on osmoregulation in Macrosiphum euphorbiae (Thomas). J Insect Physiol 56: 610-615. DOI: 10.1016/j.jinsphys.2009.12.009

Remaudiere G, Remaudiere M. 1997. Catalogue des Aphididae du Monde: Homoptera Aphidoidea. INRA (Institut National de la Recherche Agronomique). Paris. 1997.473 pp.DOI: 19971106802

Robert Y. 1987. Aphids and their environment. Dispersion and migration. In: Minks AK, Harrewijn P (eds.) Aphids: Their Biology, Natural Enemies and Control. Elsevier, Amsterdam. P. 299-313.

Sozonov AN. 2005. Potato virus Y in the North-Western region of the Russian Federation: dissemination, strain composition and prophylaxis of diseases, caused by it. Extended abstract of dissertation of Candidate of Biological Sciences. SPb: VIZR.

Vereschagina A, Gandrabur E. 2014. Polymorphism and damage of aphids. Int J Biol 6 (4): 124-138. DOI:10.5539/ijb.v6n4p124

Vereschagina AB, Shaposhnikov GC. 1998. Influences of crowding and host-plant on development of winged and apterous aphids. In: Nafria JMN, Dixon AFG (eds). Aphids Nat Manag Ecosyst. Proc V Int. Symp. on Aphids. Universidad de Leon, Leon. 15-19 September 1997.

Vereschagina AB. 2017. Polyphenicism of the bird cherry-cereal aphic Rhopalosiphum padi (L.) when feeding on the bird cherry ordinary Padus avium Mill. "Scientific support of the development of the agroindustrial complex in terms of import substitution": Coll. scientific works of Int. scientific and practical conf. profess. teach. composition "Scientific support of agriculture and the reduction of technological risks in the food sector." SPb, 26-28 January. 2017. Part 1 / SPSAU: $\mathrm{SPb}$. 27-30.

Vereschagina AB, Gandrabur ES. 2016. Development of the bird cherryoat aphid Rhopalosiphum padi (L.) (Homoptera: Aphidoidea) when feeding on bird cherry specimens with different vegetation periods and morpho-physiological characteristics in the North-West of the Russian Federation. Preservation of plant world diversity in botanical gardens: traditions, modernity, and prospects. Proc. Intern. Conf. dedicated to the 70th anniversary of the Central Siberian Botanical Garden (Novosibirsk, August 1-8, 2016). CSBG SB RAS, Novosibirsk.

Vlasov YI, Larina EI. 1982. Agricultural Virology. (Textbook and study guide for students of agricultural high schools). Kolos, Moscow.

Warren M, Krüger K, Schoeman AS. 2005. Potato Virus Y (PVY) and Potato Leaf roll Virus (PLRV): literature review for potatoes South Africa. University of Pretoria, Faculty of Natural and Agriculture Science, Department of Zoology and Entomology, Pretoria.

Wiktelius S. 1984. Studies on population development on the primary host and spring migration of Rhopalosiphum padi (L.) (Hom., Aphididae). $\mathrm{Z}$ Ang Entomol 97 (1-5): 217-222. DOI: 10.1111/j.14390418.1984.tb03741.x

Williams IS, Dixon AFG. 2007. Life cycles and Polymorphism. In van Emden HF, Harrington R (eds) Aphids as Crop Pests. CABI, Wallingford, United Kingdom. 